\title{
Öğretmenlerin Toplumsal Saygınlık ve İmajlarına Olumsuz Etki Eden Faktörlerin İncelenmesi
}

\author{
Taner ATMACA*
}

\begin{abstract}
Öz: Bu çalışmanın temel amacı, öğretmenlerin toplumsal saygınlığına, mesleki kimliğine ve imajına olumsuz etkisi olan, pejoratif yönü bulunan faktörlerin öğretmenlerin görüşlerine göre incelenmesidir. Öğretmen kimliği, Türk toplumunun hafızasında ve kadim geleneğinde saygın ve entelektüel arka planı sağlam bir yapıya sahipken zaman içerisinde ortaya çıkan çeşitli faktörlerin etkisi ile güç kaybına uğramış durumdadır. Bu faktörlerin, toplum nazarında kabul görmüş öğretmen kimliğini ve imajını zedeleyici, öğretmenin itibarına zarar verici yönleri bulunmaktadır. Araştırmanın temel eksenini farklı mesleki kıdem, dünya görüşü, pedagojik anlayış ve branşlarda görev yapan öğretmenlerin görüşleri doğrultusunda kendi mesleki kimliklerinin ve toplumsal imajlarının hangi faktörlerin etkisi ile bulunduğunu ya da bulunması gereken yerden uzaklaştığını ortaya koymak oluşturmaktadır. Çalışma betimsel tarama modelinde nitel bir araştırmadır. Bu bağlamda toplamda 10 öğretmenle derinlemesine görüşmeler yapılmıştır. Araştırmanın verileri içerik analizi ile çözümlenmiştir. Temaların oluşturulmasında NVIVO 12 programından yararlanılmıştır. Araştırma bulguları öğretmenlerin görüşlerine göre en çok profesyonellikten yoksun olmanın, özlük haklarında görülen düşüşün, medyaya yansıyan olumsuz haberlerin, olumsuz siyasi söylemlerin öğretmen kimliğini örselediğini ve toplumun imgeleminde olması gereken konumdan uzaklaştırdığını göstermektedir.
\end{abstract}

Anahtar Sözcükler: Öğretmen Kimliği, Mesleki Kimlik, Toplumsal Saygınlık

\section{Examining Factors That Negatively Affect Teachers' Social Dignity and Image}

\begin{abstract}
The main purpose of this study is to investigate the factors that have had negative effects on teachers' sense of dignity, professional identity, and self-image; these factors can also (according to qualitative findings gathered from teachers themselves) be seen as degrading or humiliating. The profession of teaching has traditionally been afforded a high level of respect in Turkish society, and for a long period of time was seen as a highly desirable occupation for the academically inclined, but has recently suffered a precipitous drop in status due to a number of factors which have contributed to the maligning of the professional identity and public image of teachers. This study focuses on uncovering and delineating the factors that underlie the worldview, sense of status and rank, pedagogical understanding, and professional opinions of teachers working in different disciplines as well as the factors that affect their professional identities and the public's perception of their profession. The study was designed using qualitative descriptive research methods. In-depth interviews were conducted with a total of 10 teachers; the resultant data was subsequently analyzed using content analysis. The program NVIVO 12 was used to categorize and classify the data. The findings of the study indicate that the lack of professionalism, decrease in personal rights, negative coverage in the media, and negative political discourse regarding the profession of teaching have all had deleterious effects on teachers' professional identities and self-image and have diminished the importance of the profession in the view of the public.
\end{abstract}

Keywords: Identity, Professional Identity, Social Respectability

* Düzce Üniversitesi, Eğitim Fakültesi, Temel Eğitim Bölümü, Düzce, Türkiye, e-posta: taneratmaca@duzce.edu.tr, ORCID: https://orcid.org/0000-0001-9157-3100 
Toplumun dinamik yapısının olması ve yeni gelişmeler doğrultusunda değişim göstermesi meslekleri de etkilemektedir. Mesleklere olan bakış açısı, mesleklerin statüsü ve toplumsal prestiji bu değişimler doğrultusunda farklılaşmaktadır. Özellikle ekonomik yapıda meydana gelen hızlı değişimlerle beraber mesleklerin toplumsal anlam katmanları da değişmektedir. Mesleki saygınlığı sağlayan temel göstergeler arasında ekonomik kazanç ve eğitim seviyesi önemli iki belirleyici olarak belirtilmektedir (Sunar ve Kaya, 2018). Öğretmenlik mesleği de profesyonel bir uğraş olarak saygınlık ve imaj bağlamında çeşitli araştırmalara konu olmaktadır ve öğretmenliğin toplumsal saygınlığını ve imajını belirleyen faktörler, hem ulusal hem de uluslararası eğitim literatüründe önemli yer tutmaktadır (Hargreaves, 2009; Hoyle, 2001; Smak ve Walzcak; 2017; Şanlı ve Arabac1, 2017; Ünsal, 2018).

Öğretmenlik mesleğinin birçok ülkede saygınlığını kaybetmesi Uluslararası Çalışma Örgütü (ILO) tarafından öğretmenliğin "kuşatma altındaki meslek" olarak nitelendirilmesine de yol açmıştır (Yurdakul, Çelik, Gür ve Kurt, 2016). The Varkey Foundation tarafından gerçekleştirilen ve öğretmenlerin saygınlık düzeylerini çeşitli göstergeler etrafında karşılaştırmalı şekilde sunan Global Teacher Satus Index (2018) raporuna göre Türkiye' de öğretmenlerin mesleki saygınlıkları 2013-2018 yılları arasında yaklaşık 10 puan ve 4 basamak birden gerilemiştir. Bu gerilemenin arkasında yatan pek çok faktörden söz edilebilir. Yapılan bazı araştırmalara göre öğretmenlerin saygınlıklarını kaybetmesinin gerisinde yatan çeşitli nedenler bulunmaktadır. Bunlar arasında yazılı-görsel ve sosyal medya, özlük hakları, bakanlığın yönetim politikaları ve sorunlara duyarsızlığı, veli baskısı, öğretmenlerin kendilerini geliştirmemeleri, eğitimdeki başarısız tablo gibi pek çok faktör sıralanmaktadır (Çetin ve Ünsal, 2018; Demir ve Arı, 2013; Tehseen ve Hedi, 2015; Ünsal ve Bağçeci, 2016). Öğretmenlerin toplumsal statü ve saygınlıkları, mesleki kimlik ve imajları sayılan bu ve benzeri nedenlerden dolayı hem öğretmenlerin kendi algısında hem de toplumsal algıda giderek düşmektedir.

Mesleklere atfedilen statü ve saygınlık göstergeleri toplumdan topluma değişkenlik göstermektedir (Andersen ve Werfhorst, 2010; Heinz, 2009). Mesleklerin saygınlığında etkili olan faktörler arasında özlük hakları, sosyal imkânlar, ekonomik kazanç ilk sıralarda yer almaktadır (Erzen ve Epçaçan, 2018). Bununla beraber iş tatmini, iş güvenliği, popülerlik, profesyonellik, kendini gerçekleştirme fırsatı, toplumsal güven, seçkinlik hissi gibi farklı faktörlerin de bir mesleğin saygınlığında etkisi oldukça yüksektir (Czeranowska, 2016). Öğretmenlik mesleğinin saygınlık düzeyi ülkeden ülkeye farklılık gösterse de hala hem dünya genelinde hem de Türkiye'de öğretmenler saygın bir meslek yapmaktadır (Dolton, Marcenaro, De Vries ve She, 2018). Türk tarihinin kadim yazılı kaynaklarına ve sözlü kültürüne yansıyan çeşitli ifadelerden anlaşıldığı şekliyle âlimlerin, ediplerin, öğretmenlerin ve bilginlerin Türk toplumu içerisinde son derece saygın bir statüsü olduğu bilinmektedir (Akyüz, 1999, 2012; Annaberdiyev, 2018; Binbaşığlu, 2014; Çiftcioğlu, 2008; Kaya, 2008; Örge-Yaşar, 2007). Bu saygınlığı sağlayan temel faktörlerin başında ise öğretmenlerin temsil ettiği insani ve mesleki değerler sayılabilir. Örneğin, Aslan'ın (2015) TALIS 2008 verilerinden yola çıkarak ulaşttı̆g 1 karşılaştırmalı sonuçlara göre Türkiye' de öğretmenlerin \%72'ye yakın kesimi mesleklerinin toplumda saygın olduğunu düşünürken bu oran Kuzey Kore için \%42 civarındadır. Ancak her meslekte olduğu gibi öğretmenlik mesleğinde de mesleğin saygınlığına zaman zaman gölge düşmektedir. Zamanla aşınan bu insani ve mesleki değerler, öğretmenlerin toplumsal saygınlıklarına olumsuz etki etmektedir. Çeşitli toplumsal gelişmeler ve dönüşümler, öğretmen yetiştirme sistemindeki değişiklikler, meslek seçiminde etkili faktörler, sosyolojik hareketlilikler, ekonomik nedenler, mesleki beklentiler öğretmenlik mesleğinin toplumsal konumunu değiştirmekte etkili olmuştur (Buyruk, 2013; Işık, 2014; Yıldız, 2014).

Yıldız (2014) toplumu dönüştüren, bilgiyle özdeşleşmiş, entelektüel yönü baskın, iyiyi, doğruyu, ahlaklı ve erdemli olanı öğreten ve bu özellikleriyle öğrencilerinin hayatlarını değiştirme gücünü elinde bulunduran öğretmen yerine artık sınava hazırlayan öğretmen imajının baskın hale geldiğini belirtmektedir. Öğretmenliğin mesleki pratiklerinde gözlenen bu radikal dönüşümle beraber mesleğin toplum nezdinde saygınlığını muhafaza eden değerlerin de aşınmasıyla bir itibar kaybı söz konusu olmaktadır. Bu kaybı hızlandıran diğer başat bir faktör ise Yıldız'a (2014) göre eğitimde uygulanan neoliberal politikalardır. Neoliberalizmle beraber piyasa endeksli bir anlayışa geçen eğitim, öğretmenin rollerini değiştirdiği gibi öğretmenden beklentileri de farklı bir forma dâhil etmiştir. İdealist-toplumcu öğretmenden zamanla sınava 
hazırlayan teknisyene dönüşen öğretmenin, meta haline getirilen bilgiyi mekanik şekilde aktaran ve öğretmen rolünü sınav başarısını esas referans noktası olarak belirleyen politikaların da saygınlığın kaybedilmesinde payı oldukça yüksektir. Keskin (2012), öğretmen rolünün bu marjinal dönüşümünü yine neoliberal politikalar endeksli olarak piyasalaşan, alınıp-satılabilen bir metaya dönüşen eğitim hizmetlerinde öğretmenin yalnızca iyi bir getiri sağlayan (sınav puanı) aktör konumuna itilmesinin önemli bir değer yitimi olduğunu belirtmektedir. Bu durum Ünal'ın (2005) betimlemesiyle "toplumsal ideallerinden" uzaklaşmasıyla beraber öğretmenleri, değer ve etikten çok, beceri ve yeterlik üzerine bir kimlik inşasına yöneltmiştir. Standart ölçümler ve çeşitli sınav göstergeleri üzerinden performansları değerlendirilen öğretmenlerin bu yönü toplumsal kimlikten kopartılarak niteliğinin ve saygınlığının azalmasını da hızlandırmış bulunmaktadır.

Uygun (2012), toplumsal sorunlara karşı duyarlı davranış geliştiren, halkın gerçek yaşantısından kopmamış ve halkla bütünleşmiş öğretmenlerin mesleki saygınlıklarının daha yüksek olduğunu dile getirmektedir. Celep (2004), öğretmenlerin toplumu yeniden inşa etme görevleri ve sorumlulukları bulunduğu için saygınlığın en önemli kaynağını öğretmenlerden beklenen bu özelliklerin oluşturduğunu ifade etmektedir. Çocukların ve gençlerin toplumsallaşmalarında, çeşitli değerleri öğrenmelerinde, farklı yönlerden gelişim göstermelerinde öncü aktör olarak görülen öğretmenin bu rolü, onu özellikle Türk toplumu gibi geleneksel yönü güçlü toplumlarda üst katmanlara taşımaktadır (Eskicumalı, 2001).

Türkiye'de cumhuriyetin ilanı ile beraber öğretmenlerin yeni yönetim biçiminin görünen yüzleri olması ve bu sistemin halk nezdinde kabul edilmesi ve anlaşılması noktasında kendilerine görev verilmiş olması toplumsal yönlerinin öne çımmasında etkili olmuştur. Bu durum toplumsal statülerinin güçlenmesinde ve saygınlık kazanmalarında da rol almıştır (Bek, 2007). Ancak özellikle 20. yüzyılın ikinci yarısından itibaren değişen ekonomik, sosyal ve kültürel yapı daha fazla para kazanılan mesleklerin daha saygın olduğu algısını oluşturmuş ve bu bağlamda öğretmenlik mesleğinin itibarında eskiye göre bir düşüş meydana gelmiştir (Arslanoğlu, 1992). Öğretmenlik mesleğinin saygınlığının göstergeleri olarak ele alınan diğer bir faktör ise sunulan hizmetin toplumsal değeridir (Ulutaş, 2017). Hoyle (2001) öğretmenlerin mesleki imajlarının oluşmasında kişilik özellikleri, ekonomik kazanç seviyesi, öğretmenin profesyonelleşmiş olması, alan uzmanlığı ve pedagojik yetkinliği gibi faktörleri sıralamaktadır. Walhout (2011, akt. Ünsal ve Bağçeci, 2016) öğretmenlerin toplum üzerinde oluşturduğu etki değerinin meslek imajını belirleyen ana faktör olduğunun altını çizmektedir.

Öğretmenlik mesleğinin Türkiye'de toplumsal saygınlığı ve imajı son zamanlarda yaşanan bazı siyasi, ekonomik ve sosyal gelişmelere bağlı olarak değişiklik göstermektedir. Bu değişimin arkasında yatan ve birbirinden farklı veya birbiri ile bağlantılı pek çok kaynaktan söz etmek mümkündür (Özdemir ve Orhan, 2019). Öğretmenlerin rol ve sorumluluklarının fazlalığı ve çeşitliliği, eğitimden beklentilerin artması, kamuoyunda ve medyada sıklıkla gündeme gelen eğitimde başarı göstergeleri, okullarda yaşanan çeşitli sorunlar gibi öğretmenleri doğrudan ve dolaylı olarak ilgilendiren konular dikkatlerin bu mesleğe ve bu mesleği yapanlara çevrilmesine de zemin hazırlamaktadır (Demir ve Arı, 2013; Ünsal, 2018). Öğretmenleri ilgilendiren bu başlıkların bir şekilde onların mesleki statü ve saygınlıklarına da etkisi olduğu düşünülmektedir.

Öğretmenlerin toplumsal saygınlıklarının yüksek olmasının öğrenme ve öğretme pratikleri üzerinde olumlu yansımalarının olacağı tahmin edilmektedir. Mesleki saygınlık ve imajın düşük olması öğretmenlerin mesleklerine olan bakış açlarını ve motivasyonlarını da olumsuz etkileyebilmektedir. Ancak Türkiye örneklemi üzerinde yapılan literatür taramasında öğretmenlerin kendi algılamalarına göre mesleklerinin saygınlığını ve imajını olumsuz etkileyen faktörlerin neler olduğu ve bu faktörlerin birbirleriyle olan ilişkisinin nasıl şekillendiğine dair çalışmaların oldukça az olduğu görülmektedir (Bozbayındır, 2019; Erzen ve Epçaçan, 2018; Ulutaş, 2017). Bu araştırma “Öğretmenlerin görüşlerine göre öğretmenlik mesleğinin saygınlığını azaltan faktörler nelerdir? sorusuna cevap aramaktadır.

\section{Araştırmanın Amacı}

Bazı olumsuz gelişmelere ve durumlara rağmen öğretmenlik mesleğinin dünyada hala en güvenilir ve saygı duyulan meslekler kategorisinde yer alması umut verici bir durumdur. Ancak meydana gelen çeşitli 
gelişmelerin özellikle Türk kültüründe saygın bir yeri olan öğretmenlik mesleğinin zaman zaman imajında zedelenmelere yol açtığı düşünülmektedir. Alan yazında öğretmenlik mesleğinin saygınlığını ve imajını olumsuz etkileyen faktörlere ilişkin farklı araştırma bulguları yer almakla beraber bu durumu deneyimleyen öğretmenlerin ortak deneyimlerinden hareketle ortak faktörlerin ortaya çıkarılması amaçlanmıştır. Bu bağlamda araştırmanın ana amacı, öğretmen görüşlerine göre öğretmenlik mesleğinin saygınlığını azaltan güncel durumların neler olduğunu ortaya koymak olarak belirlenmiştir.

\section{Yöntem}

$\mathrm{Bu}$ bölümde araştırmanın modeli, veri toplama araçları ve çalışma grubuna ilişkin çeşitli bilgiler sunulmuştur.

\section{Araștırmanın Modeli}

$\mathrm{Bu}$ çalışma, öğretmenlerin var olan bir durumu olabildiğince etraflı tanımlamalarını içerdiği için (Büyüköztürk, Çakmak, Akgün, Karadeniz ve Demirel, 2012) betimsel tarama modelinde tasarlanmıştır. Tarama modeli, geçmişte ya da halen var olan bir durumu olduğu şekliyle betimlemeyi amaçlamaktadır (Karasar, 2015).

\section{Örneklem}

Araştırmanın örneklemi, ortaya konulan problemi geniş bir perspektifte ve farklı cephelerden ele almak için olasılıklı olmayan örneklem belirleme tekniklerinden maksimum çeşitlilik örnekleme metodu ile oluşturulmuştur. Maksimum çeşitliliğe dayalı bir örneklem oluşturmadaki amaç, genelleme yapmak için bu çeşitliliği ortaya koymaktan çok çeşitlilik gösteren durumlar arasındaki benzerliği yakalayabilmektir (Yıldırım ve Şimşek, 2013). Maksimumum çeşitlilikte öğretmenlerin çalıştıkları okul kademesi, çalıştıkları şehir, mezuniyet derecesi, mesleki kıdemleri ve branşlar esas alınmıştır. Örneklem içerisinde kadın öğretmen sayısının bir kişi olması ve sendikası bulunmaması ise çeşitlilik için bir sınırlılıktır. Örneklemin birbirinden farklı okul türü-kademesinde ve şehirlerde çalışan ve farklı mezuniyet derecelerine sahip, yöneticilik deneyimi olan öğretmenlerden oluşmasına farklı perspektifleri ve deneyimleri yakalayabilmek adına dikkat edilmiştir. Çalışmaya birbirinden farklı branşlarda, mesleki kıdemde ve eğitim sendikasında bulunan 10 öğretmen katılmıştır. Örneklem oluşturulurken katılımcıların tümüyle gönüllü olmasına öncelik verilmiştir. Ayrıca birbirinden farklı ilçelerde görev yapmalarına, aynı okulda iki öğretmenden fazla kişiyle görüşme gerçekleştirmemeye maksimum çeşitlilik ekseninde dikkat edilmiştir. Katılımcılara ilişkin demografik özellikler Tablo 1'de sunulmuştur.

Tablo I

Katılımo öğretmenlerin bazı demografik özellikleri

\begin{tabular}{ccccccccc}
\hline Rumuz & Cinsiyet & Kidem & İl & $\begin{array}{c}\text { Okul } \\
\text { kademesi }\end{array}$ & Branşı & Sendikası & Mezuniyeti & $\begin{array}{c}\text { Görüssme } \\
\text { Süresi }\end{array}$ \\
\hline Ö1* & Erkek & 21 & Düzce & Lise & Tarih & Var & Yüksek L. & $38 \mathrm{dk}$. \\
\hline Ö2 & Erkek & 15 & Ankara & Lise & Edebiyat & Var & Lisans & $45 \mathrm{dk}$. \\
\hline Ö3* & Erkek & 15 & Düzce & Ortaokul & Tasarım & Var & Yüksek L. & $27 \mathrm{dk}$. \\
\hline Ö4 & Erkek & 18 & Düzce & Lise & Grafik & Var & Lisans & $17 \mathrm{dk}$. \\
\hline Ö5 & Erkek & 14 & İstanbul & İlkokul & Sinıf & Var & Lisans & $32 \mathrm{dk}$. \\
\hline Ö6 & Kadın & 7 & İstanbul & İlkokul & PDR & Yok & Lisans & $36 \mathrm{dk}$. \\
\hline Ö7 & Erkek & 16 & Düzce & Lise & Bilişim & Var & Lisans & $28 \mathrm{dk}$. \\
\hline Ö8 & Erkek & 19 & Ankara & Lise & Matematik & Var & Yüksek L. & $19 \mathrm{dk}$. \\
\hline Ö9 & Erkek & 14 & Yozgat & İlkokul & Sinif & Var & Lisans & $23 \mathrm{dk}$. \\
\hline Ö10* & Erkek & 16 & Sivas & Ortaokul & Sinif & Var & Lisans & $34 \mathrm{dk}$. \\
\hline
\end{tabular}

Tablo 1'e bakıldığı zaman katılımcı öğretmenlerin 9'unun erkek, 1'inin kadın olduğu, 5'inin lise kademesinde, 2'sinin ortaokul kademesinde, 3'ünün de ilkokul kademesinde görev yaptığ görülmektedir. Katılımcı öğretmenlerin mesleki kıdemleri 7 yıl ile 21 yıl arasında değişmektedir. Dokuz öğretmen herhangi bir eğitim sendikasına bağlı iken bir öğretmenin sendikası yoktur. Üç öğretmen (Rumuzun yanında * işareti olanlar) aynı zamanda okul müdürlüğü de yapmaktadır. Üç öğretmenin yüksek lisans derecesinde, yedi 
öğretmenin ise lisans derecesinde mezuniyeti bulunmaktadır. Görüşme süreleri 17 ile 45 dakika arasında değişmektedir. Katılımcıların dördü Düzce'den, ikisi Ankara'dan, ikisi İstanbul'dan, birisi Yozgat'tan, birisi de Sivas'tandır. Katılımcıların tümü kadrolu öğretmendir.

\section{Veri Toplama Aracı ve Verilerin Toplanması}

Araştırmacıya görüşme esnasında esneklik tanıdığı ve görüşmenin gidişatına göre çeşitli ek ve sonda sorular sorma imkânı verdiği için çalışmada yarı yapılandırılmış görüşme formu kullanılmıştır. Yarı yapılandırılmış formlar, araştırmacının incelediği insan deneyimlerinin derinliklerine inmesinde önemli bir yardımcıdır (Patton, 2014). Görüşme formu hazırlanmadan önce alana ilişkin yerli ve yabancı literatür okunmuş ve araştırma problemini etraflıca ortaya koymayı amaçladığı düşünülen toplam 6 adet ana soru hazırlanmıştır. Görüşmelerin gidişatına göre ana sorulara bağlı sonda sorulara da yer verilmiştir. Ana görüşmelerden önce 2 öğretmenle pilot görüşmeler yapılmıştır. Soruların açıklığı, anlaşılırlığı, araştırmanın amacıyla örtüşüp örtüşmediği bu pilot görüşmeler neticesinde belirlenmiş ve bu doğrultuda çeşitli revizyonlara gidilmiştir. Formun son hali düzeltmeler sonunda ortaya çıkmıştır. Veriler Ağustos-Ekim 2019 periyodunda elde edilmiştir. Katılımcılarla görüşme yüz yüze ve çalıştıkları okullarda ya da uygun gördükleri farklı ortamlarda randevu alınarak gerçekleştirilmiştir. Görüşmeler 17-45 dakika arasında sürmüştür. Katılımcılardan izin alınarak (imzalı onam formu ile) ses kayıtları, kayıt cihazına alınmıştır. Katılımcılara yöneltilen bazı örnek sorular şu şekildedir:

1. Bir mesleği saygın yapan nedir sizce ve öğretmenlik mesleğinin profesyonelliği ve saygınlığı hakkında ne düşünüyorsunuz? Önceki yıllara göre öğretmenlik mesleğinin saygınlığında değişsim - düşüş var mı sizce?

2. Öğretmenlik mesleğinin saygınlığını düşüren faktörler günümüzde neler olabilir sizce?

3. Öğretmenlik mesleğinin toplumsal saygınlığını olumsuz etkileyen faktörler sizce nelerdir? Bu faktörlerin gittikçe daha sık etki etmeye başladığını düşünüyor musunuz?

\section{Verilerin Analizi}

Öğretmenlerden elde edilen ses kayıtları öncelikle yazıya aktarılmıştır ve toplamda 18 sayfa Word dosyası meydana gelmiştir. Verilerin çözümlenmesinde içerik analizinden yararlanılmıştır. İçerik analizi, görüşme esnasında elde edilen verilerden birbiri ile paralel olanları ortak tema altına getirerek düzenlemeyi içermektedir (Yıldırım ve Şimşek, 2013). Araştırmanın geçerliliğinin sağlanmasında katılımcı teyidi esas alınmıştır. Veriler çözümlendikten sonra yeniden katılımcılara dosyalar e-posta atılmak suretiyle katılımcı teyidi elde edilmiştir. Araştırmanın güvenirliğinde Yıldırım ve Şimşek'in (2013) belirttiği üzere doğrudan alıntılara ve betimlemelere yer verilmiştir. Veriler analiz edilirken aynı sorulara cevap veren tüm katılımcıların cevapları alt alta yazılmış ve bu cevaplardan çeşitli kodlar ve kodlardan hareketle de temalara ulaşılmıştır. Bu bağlamda dört ana temanın oluştuğu görülmüştür. Bu temalar sırasıyla Öğretmenlik Mesleğinin Profesyonelliğinin Düşüşü, Öğretmenlerin Özlük Haklarının Yetersizliği, Medyaya Yansıyan Olumsuz İçerikli Öğretmen Haberleri ve Öğretmenlere Yönelik Olumsuz Siyasi Söylemler şeklindedir.

\section{Araştırmada İzlenen Etik İlkeler}

Araştırmacının bu süreçte çeşitli etik ilkelere uymuştur. Bunlar arasında araştırma başlamadan önce katılımda gönüllülüğün esas alındığını, katılımcıların kimliklerinin deşifre edilmeyeceğini, ses kayıtlarının kendilerinin yazılı onamları dâhilinde alınacağını, verilerin bilimsel çalışma amacının dışında farklı kişi ve platformlarla paylaşılmayacağını, kendilerinin neden seçildiğini katılımcılara bildirmek olmuştur.

\section{Bulgular}

Bu bölümde araştırmada elde edilen verilerin çözümlenmesi ile ortaya çıkan bulgulara ve yorumlarına yer verilmiştir. Araştırmanın verileri öğretmenlerin mesleki saygınlıklarına ve imajlarına olumsuz etki yapan temel faktörlerin profesyonelliğin azalışı, özlük haklarında meydana gelen düşüş, medyaya yansıyan haberler, siyasilerin ve bürokratların söylem ve davranışları olarak dört ana tema etrafında toplandığını göstermektedir. 


\section{Öğretmenlik Mesleğinin Profesyonelliğinin Düşüşü}

Araştırmadan elde edilen veriler doğrultusunda ilk tema olarak öğretmenlik mesleğinin profesyonelliğinin düşüşü ortaya çıkmıştır. Katılımcı öğretmenlerin mesleklerinin profesyonellikleri ve saygınlıkları ile ilgili algıları ve bu durumu etkilediklerini düşündükleri çeşitli faktörler bu tema altında verilmiştir. Öğretmenlik mesleğinin profesyonelliğini etkileyen çeşitli faktörler öğretmen görüşlerinde öne çıkmaktadır. Söz gelimi, mesleki profesyonellikle ilgili bir öğretmenin ifadeleri şu şekildedir:

Öğretmenlik mesleği benim gözümde kariyer mesleğidir. Buradaki en önemli zedeleyici unsur ise devletin eğitim politikalarıdır. Öğretmeni gerçekten hem özlük hakları hem de devletin eğitim politikaları bakımından önemli bir yere koyarsanız üniversiteler de kendini ona göre şekillendirir. Öğretmenlik mesleğini tercih edenlerin hem ahlak hem zekâ hem de kişilik olarak nitelik sahibi kişilerin tercih etmesini să̆layacaktır. Bu da statüyü artıracaktır. (Ö3)

Yukarıdaki ifadelere göre öğretmenlik mesleğinin profesyonelliğini etkileyen önemli faktörler arasında devletin eğitim politikalarına, mesleğe aday kişilerin kişilik ve karakter özelliklerine, öğretmenlerin özlük haklarına, üniversitelerdeki öğretmen eğitimlerine vurgu yapılmaktadır. Bu faktörlere dikkat edildiğinde profesyonelliğin artacağı ve bunun da saygınlığı yükselteceğine işaret edilmektedir.

Öğretmen profesyonelliğini ve saygınlığını olumsuz etkileyen diğer bir durum ise farklı bir öğretmene göre alan dışı atamalar ve yetkinliği olmayan kişilerin özellikle teknik alanlardaki istihdam usulleridir. Belirli branşlarda yapılan yan dal atamalarla gelen kişilerin alandaki yetkinliği sağlayamadığı dile getirilmektedir. Bu durumun da öğretmen profesyonelliğine olumsuz yansıdığını aşağıdaki sözlerde görülmektedir:

Hak edilmeyen atamaların hak edilmeyecek şekilde yapılması büyük sorundur. Resim öğretmeninin grafik branşına atanması gibi. Bunu hem kendi bölümümden ve diğer bölümlerden biliyorum. Yani hiç bilgisayar bilmeyen, hiçbir profesyonel programı kullanamayan öğretmenin grafik bölümüne atanması buna örnektir. Öğretmen kendi alanın bilmiyor bir kere! Nitelik çok önemlidir. (Ö4)

Öğretmenlerin toplumun aydın, okuyan, yazan, düşünen, tartışan, soran ve sorgulayan kesimini temsil ettiği varsayımı ve öğretmen kimliğine yapılan bu yakıştırma ve kurulan özdeşimler öğretmenlerden beklentileri de bu yöne sevk etmektedir. Ancak mesleğin içerisinde yer alan öğretmenlerin kendi profillerini bu beklentileri karşılayacak türde bir imge ile bütünleştirmemeleri mesleğin statüsü ve saygınlığına olumsuz etki edebilmektedir. Bu durumu destekler nitelikte katılımcı bir öğretmenin ifadeleri şu şekildedir:

\footnotetext{
Okumanın, yazmanın, kültürel pratiklerin saygınlkla çok büyük bir bağı vardır. Kendimi ve okuldaki meslektaşlarımı entelektüel yönden yeterli bulmuyorum. Mesela biz çocuklara okuma yazmayı sevdirmeye çalışıyoruz ama öğretmen olarak kendimiz bunu yapmıyoruz, kendim de dâhil. Ancak hitap ettiğimiz kitle de bizden çok büyük bir entelektüellik beklemiyor, veliler yönünden yani. Bu bölgede (İstanbul-Çekmeköy/Taşdelen) çok fazla entelektüel yöne sahip olmadan da öğretmenlik yapılabiliyor. Bize daha çok artık bakıcı muamelesi yapılıyor. (Ö5)
}

Yukarıdaki sözler öğretmenliğin profesyonelliğini gösteren önemli bileşenlerinden entelektüel kimliğe dair öğretmenin kendine yönelik öz eleştirisi ve meslektaşlarına dönük değerlendirmelerini içermektedir. Meydana gelen çeşitli sosyolojik, ekonomik, teknolojik ve siyasi değişimlerle beraber toplumun öğretmenlere bakış açısında geçmiş dönemlere göre farklılık olduğu ve öğretmenlerden beklentilerin de değiştiği düşünülmektedir. Bilginin yegâne kaynağı olarak görülen ve bu özelliğinden dolayı da toplumda önemli bir konumda, el üstünde tutulan öğretmenlerin konumlarındaki sarsıntı bilginin erişilmesindeki seçeneklerin çoğalması ile artmıştır. Bu konuya ilişkin bir öğretmenin ifadeleri şöyledir:

Eskiden gelen bir kültür vardı, öğretmenler çocuklarımızın menfaatini ister algısı vardı. Şimdi o algı toplumda artık pek yok. Veli artık yeri geldiğinde öğretmene işini öğretircesine müdahil olabiliyor. Hatta çocuğumun hakkını koruyorum diye öğretmene yönelik taciz içeren eylemleri de görüyoruz. Bu da öğretmenin motivasyonun ve profesyonelliğinin sarsilmasına sebep olmaktadır. (Ö1)

Öğretmenlerin toplumsal saygınlıklarını doğrudan ve dolaylı olarak etkilediği düşünülen önemli bir faktör olarak özlük haklarına vurgu yapılmıştır. Elde edilen bulgulardan hareketle ikinci tema olan Öğretmenlerin Özlük Hakları oluşturulmuştur.

\section{Öğretmenlerin Özlük Haklarının Yetersizliği}

Mesleklere bakış açısının önemli bir göstergesi de artık günümüzde mesleğin sunduğu özlük hakları olarak görülmektedir. Özlük hakları içerisinde en önemli başlığı ise elde edilen gelir oluşturmaktadır. 
Öğretmenlik mesleğinin Türkiye özelinde çok kazandıran meslekler grubunda yer almaması mesleklerin ekonomik kazanca dayalı statü hiyerarşisinde öğretmenliğin çok üstlerde yer almamasına neden olduğu düşünülmektedir. Bu duruma ilişkin bir katılımcı öğretmenin ifadeleri “Öğretmenlerin ekonomik gelirlerini yükseltsek de kendilerini geliştirecekleri ortamları da politikaları da sağlamamız lazım. Böyle bir anlayışın oluşması gerekir. (Ö7)" şeklindedir. Bu öğretmene göre salt ekonomik iyileştirme belirli bir alan oluştursa da bu iyileştirmelerin mesleğin profesyonelleşmesine katkı sunmaması halinde bir şey ifade etmeyeceğinin de altı çizilmektedir. Farklı bazı öğretmenlerin ifadeleri ise şöyledir:

Öğretmenlerin gelirlerinde önemli iyileştirmeler olursa saygınlıklarında mutlaka bir değişme olacaktır. Çünkü yaşam tarzı değ işir, biraz daha kendine zaman ayırabilir, eğer maddi sıkıntılardan kurtulursa biraz daha entelektüel işlerle uğraşabilir. Kitap okuyabilir, sinemaya gidebilir, kültürel faaliyetlere daha çok katılır. Borcunu düşünmediği zaman kendini işine verebilir. (Ö5)

Öğretmen gelirleri şu an orta düzeyde sayılabilir ancak bölgesel düşündüğümüzde bu durum değişmektedir. Kentleşmenin etkisi ile satın alma gücü düşmektedir. Kır-kent bağlamında öğretmenin kazancı ve satın alma gücü velinin algısını da değiştirmektedir. Şehirlerde ekonomik bağlamda öğretmene bakış gerçekten çok düşük. Öğretmenin bu şekilde değersizleştirilmesi hem çalışma motivasyonunu düşürüyor hem de öğrencinin akademik başarısına olumsuz aksediyor. (Ö8)

Özellikle büyük şehirlerdeki ekonomik gerçekliklerin toplumun mesleklere ve o mesleği yapanlara bakışında önemli bir belirleyici olduğunun altı çizilmektedir. Öğretmenlerin kendi mesleklerini daha iyi nasıl yürütebileceklerine ilişkin çabaları geçim kaygısının gerisinde kalması bu bakış açısının ortaya çıkmasında da başat faktördür. Öğretmenlerin diğer özlük hakları ve ayrıcalıklarının da farklı kariyer mesleklerine göre yeterince olmaması benzer şekilde mesleğin toplumsal algısını şekillendirmede etkisi olan unsurlar içinde yer almaktadır.

\section{Medyaya Yansıyan Olumsuz İçerikli Öğretmen Haberleri}

Katılımcı öğretmenlere göre öğretmenlerin mesleki saygınlıklarının düşmesinde diğer önemli bir faktör yazılı, görsel ve basılı medyaya yansıyan öğretmenlere yönelik olumsuz içeriği bulunan çeşitli haberlerdir. Özellikle öğretmenlerin olumsuz bir imajla yer aldığı ve çoğunlukla da bu tür haberlerin taciz, istismar, şiddet vb. içermesi mesleğin ve temsilcilerinin imajını kötü etkilediği düşünülmektedir. Bu duruma ilişkin bazı öğretmenlerin düşüncelerine aşağıda yer verilmiştir:

Öğretmenin iyi bir eylemi ile basına yansımasına pek rastlanmazken aksi bir durumda işte örneğin cinsel istismardır, dayaktır, ihmaldir vb. bu tür olayların daha fazla reyting aldığı bir gerçek. Bunların halk nezdinde öğretmenlere karşı ciddi yan etkiler oluşturduğuna şahit oluyoruz. Eskiye nazaran öğretmenliğin statüsünün düştüğ̈̈nün ve değerinin azaldığının altın çizebiliriz. (Ö2)

Şüphesiz ki TV'ler insanların algısını dehşet derecede etkiliyor. TV'de ya da internette bu haberlerin yayılması elbette insanların tepki ve nefretini çektiği için meslek üzerindeki olumsuz etkisi elbette ki var. Bu nitelikte medyaya yansıyan haberlerin olmamasını temenni ediyorum, keşke hiç olmasa. (Ö1)

Medyanın sürekli olarak bu yönde bir algı oluşturmasının ailelerin oldukça hassaslaşmasına ve öğretmenlere karşı tepkisel davranışlar üretmesinde son derece etkili olduğu düşünülmektedir. Söz gelimi, bir öğretmenin (Ö6) sözleri bu yönde ele alınabilir: “Geçen gün ilkokul birinci sınıf öğrencisi bana diyor ki seni babama söylerim, yani böyle geliyorlar evden. İşte bir şey olursa, öğretmenin bir şey yaparsa, kızarsa gel bize söyle. Sanki her öğretmen sapık, her öğretmen şiddet eğilimlisidir." Ailelerin, basına yansıyan, sosyal medyada çok konuşulan bu içeriklere karşı oluşturduğu ve kendilerince haklı olan tavırları doğrudan veya dolaylı olarak öğretmenlerin ve öğretmenlik mesleğinin imajının bozulmasına zemin oluşturduğu dile getirilmektedir.

Katılımcı öğretmenlerin dile getirdiği farklı bir detay ise öğretmenlerin bizatihi kendilerinin yaptıkları sosyal medya paylaşımlarına yöneliktir. Öğretmen kimliğinin sadece okulda görev yapılan süre içerisinde sınırlandırılmayacak kadar geniş ve öğretmenliğin bir mesleğin ötesinde hayat tarzı olduğunu vurgulayan öğretmenlere göre hayatın her alanında öğretmen kimliğine ve imajına yakışır şekilde davranmak gerekmektedir. $\mathrm{Bu}$ düşünceye göre öğretmenlerin kişisel sosyal medya hesaplarından yaptıkları paylaşımların, sosyal ağda görünür olması hem bireysel imajın hem de mesleki imajın şekillenmesinde, başkalarının öğretmenliğe bakış açısının biçimlenmesinde payı yüksektir. Bir öğretmenimizin bu yöndeki görüşleri şöyledir: 
Öğretmenlerin Toplumsal Saygınlıklarına ve İmajlarına...

Öğretmenin emeklisi değil, rahmetlisi olur. Biz 8-5 çalışmakla mükellef değiliz sadece. Evet, okuldaki görevimiz bitmiş olabilir ama bizim toplumdaki sifatımız ve öğretmen görevimiz asla değişmez. Halk bizi böyle görüyor, böyle bakıyor bize. O nedenle biz bu ağırlı̆̆ı fark edebilmeliyiz. O yüzden 8-5 arası farkll, ondan sonra özgürüm deyip de ayrı bir kimlik oluşturmamız mümkün değildir. Bu bağlamda öğretmenin okul dışında yaptığı hareketler, sosyal medya paylaşımları kendisine olduğu gibi mesleğe de menfi etki oluşturmaktadır. (Ö1)

Yukarıdaki ifadeler kimliğin gündelik hayatta da sürdürülebilir hale getirilmesi gerektiğini ve öğretmenliğin teknik bir işe indirgenmek yerine topluma yön verecek bir tarza sahip olduğunu öne çıkarmaktadır. Ancak buna katılmayan öğretmenler de söz konusudur. Özellikle sosyal medya ağlarının kendilerinin özel alanı olduğu ve meslekleri ile oradaki paylaşımların uyumlu olmasının gerekmediğini belirten katılımcılar da vardır. Aşağıda alıntılanan şekliyle bir öğretmenin sözleri bu yönde ele alınabilir.

Instagram benim özel alanım ve bu bence beni ilgilendirir sadece, kişinin kendi alanına çok müdahale etmemek gerekir. Biz öğretmenin, her alana müdahale edecek hakk olduğunu düşünüyoruz. Öğretmen evde de öğretmen olsun, başka yerde de diye düşünülüyor ama katılmıyorum, rahatım ben. (Ö6)

\section{Öğretmenlere Yönelik Olumsuz Siyasi Söylemler}

Öğretmenlik mesleğinin saygınlığına zarar veren faktörler arasında olumsuz siyasi söylemler son temayı oluşturmaktadır. Öğretmenlerin görüşlerine göre mesleğin saygınlığında olumsuz etkisi bulunan diğer önemli bir faktör olarak politikacıların öğretmenlere ve öğretmenlik mesleğine yönelik söyledikleri olumsuz ifadelerdir. Bu duruma ilişkin bazı öğretmenlerin görüşlerine aşağıda yer verilmiştir:

Öğretmenlere ilişkin olumsuz siyasi söylemlerin neticesinde öğretmenlerin itibar kaybettiğini düşünüyorum. Devlet bile kendi memuruna böyle davranıyor, sonunda herkes istediği lafı söyleme hakkını kendine görüyor. Şamar oğlanına çeviriyorlar öğretmenleri. Bunlardan cesaret alanlar elini kolunu sallayarak öğretmenlere istediği lafı söylüyor, istediği şiddeti uyguluyor. (Ö9)

Bir mesleği ve temsilcilerini bu tür söylemler ile değersiz hale getirdiğimiz zaman ve tekil örnekleri sanki tüm öğretmenler böyle algısı oluşturacak şekilde sunduğunuzda bu gerçekten hem öğretmenlerin çalışma azmini ortadan kaldırıyor hem de toplum nezdinde bizi değersizleştiriyor. Öğretmenleri siyasiler kariyer mesleği olarak değil normal memurluk olarak görüyorlar. (Ö10)

Öğretmenlere yönelik sarf edilen ve toplum nezdinde etki uyandıran gerek olumsuz siyasi söylemler gerekse çeşitli bürokratların söz ve tavırlarının özellikle basın, medya ve TV'ler aracıllı̆ı ile geniş kitlelere erişmesinin sonucunda da mesleki saygınlığa zarar verildiği düşünülmektedir. Özellikle medya önünde gerçekleştirilen siyasi söylemlerin ve verilen demeçlerin öğretmenlere yönelik olumsuz argümanlar içermesi öğretmenler tarafından rencide edici ve imajlarına zarar verici bir durum olarak değerlendirilmektedir. Genel anlamda ülkenin yönetimine ilişkin politikaları belirleyen aktörlerin, daha özelde ise eğitim politikalarını şekillendiren siyasilerin ve bürokratların zaman zaman basına ve medyaya yansıyan ve öğretmenleri rencide edici sözlerin ve davranışların da toplum nezdinde öğretmenliğe olan bakışı zedelediği öğretmenler tarafından düşünülmektedir.

\section{Tartışma, Sonuç ve Öneriler}

Öğretmenlik mesleği yaşanan olumsuz gelişmelere karşın hem Türkiye'de hem de dünyada toplum nezdinde güvenilir ve saygın meslekler içerisinde üst sırada yer almaktadır (Ulutaş, 2017). Ancak son zamanlarda Türkiye örneklemi üzerinden düşünüldügünde ortaya çıan bazı faktörlerin etkisi ile mesleğin saygınlığında ve imajında olumsuz etki meydana getiren durumlara rastlanmaktadır. Araştırmanın bulgularında sıklıkla tekrarlanan ve mesleki saygınlığa zarar veren en önemli olumsuz faktörler arasında öğretmenlerin profesyonelliği yeterince sağlayamamaları ve meslek içinde gelişimlere yeteri kadar zaman ayırmamaları ilk sırada yer almaktadır. Öğretmenlik, bir kariyer mesleği ve çeşitli alanlarda profesyonel olmayı gerektiren bir uğraştır. Bu alanlar içerisinde pedagojinin temel ve güncel kavramları, çocuk gelişimi, öğrenme psikolojisi, okul sosyolojisi, nitelikli iletişim becerisi, öğretim metotlarını kullanabilme gibi pek çok bileşen sayılabilir. Bu bileşenlerin bir ya da birden fazlasının noksanlığı öğretmenlerin mesleki pratiklerini yeterince yerine getirememelerine neden olabilmekte ve bu eksiklik de velilerin gözünde öğretmenleri ve temsil ettikleri mesleğin imajını zedeleyebilmektedir.

Öğretmenlerin profesyonelliğine ilişkin beklenti ve tanımlar zamana, kültüre, tarihe, politikalara ve sosyal yapılara göre değişiklik gösterebilmektedir (Demirkasımoğlu, 2010). İş hayatında profesyonellik kavramı daha çok "başarı" eksenli bir semantik içerisinde kullanılmaktadır (Tichenor ve Tichenor, 2005). Bir alanda 
profesyonel olmak demek alanın bilgisine ve gerekli becerilere sahip olmak demektir (Baggini, 2005). Stronge (2002) öğretmen profesyonelliğinin göstergeleri olarak sınıf yönetim becerileri, kişiliği, öğretime hazırlık çalışmalarını, öğrencinin gelişim seyrini takip edebilmeyi saymaktadır. Hoyle (1980) profesyonelliği pratik beceriler ile özdeş tutmaktadır. Hurst ve Reding (2000) öğretmen profesyonelliğinin temel göstergeleri olarak uygun iletişim dilini kullanabilme, meslektaşları ile dayanışma içinde güçlü ilişkiler geliştirebilme, dakik olma gibi etkenleri sıralamaktadır. Kramer (2003) öğretmen profesyonelliğini temelde üç ana alt kategoriye ayırmaktadır. Bunlar sırasıyla tutum, davranış ve iletişimdir. Cruickshank ve Haefele (2001) ise "iyi öğretmenleri" analitik düşünebilen, yansıtıcı düşünce geliştirebilen, alanında uzman ve saygın kişiler olarak nitelemektedir. Phelps (2006) öğretmen profesyonelliğinin kendi eylem ve tutumlarına karşı geliştirdikleri eleştirel düşünce ile daha da üst seviyeye taşınacağını belirtmektedir. Appleyard ve Appleyard (2014) öğretmenin profesyonel olarak kabul edilmesi için alan uzmanı, öğretebilme uzmanı, sürekli öğrenen birey olması, öğrenmeyi yönetebilecek donanıma sahip olması, meslek etiğine yaraşır davranışlar sergilemesini dile getirmektedir. Hoşgörür (2017) yaptığı çalışmada öğretmen profesyonelliğini kişisel gelişim, kuruma katkı, mesleki duyarlılık ve duygusal emek başlıkları etrafında tartışmaktadır.

Öğretmen profesyonelliğinin göstergeleri genellikle okul içi öğrenme süreçleri ve kazanımları üzerinden değerlendirilmektedir. Öğretmen profesyonelliğini değerlendirmede kullanılan görünür ve hissedilir yönlerin başında gelen akademik başarı ve kazanımlar mesleğin ve kişinin saygınlığına da doğrudan ve dolaylı bir etki oluşturabilmektedir. Hoşgörür'ün (2017) de altını çizdiği üzere saygınlık büyük ölçüde öğretmenlerin dış dünya ile kurdukları ilişki üzerinden ele alınmaktadır. Dolayısıyla mesleki saygınlığın ve güvenin ihdas edilmesinde öğretmenlerin mesleki becerileri olduğu kadar kişisel gelişim ve öğrenme çabaları da önemli bir imaj belirleyicileri olarak literatürde yer almaktadır.

Öğretmenlik mesleğinin son zamanlarda uğradığı dönüşüm ve meslekten beklentilerin değişmesi hem profesyonelliği hem de yetkinliği etkilemektedir. Profesyonellikten uzaklaştıkça kaybedilen toplumsal statü ve saygınlığın çeşitli mesleki etkileri olabilmektedir. Bunlar arasında Topkaya, Altınkurt, Yılmaz ve Dilek'in (2013) belirttiği üzere öğretmenlerin kaygı düzeylerinin artması, mesleki yabancılaşma içine girme, performansın azalması, örgütsel sinizm yaşama gibi farklı sonuçlar sıralanmaktadır. Öğretmenlik mesleğinin neoliberal ekonomi ve eğitim politikalarının sonucunda Yıldız'ın (2014) deyimiyle idealist formundan uzaklaştırılarak teknik bir işe indirgenmesi de bu tablonun ortaya çıkmasında etki gücü yüksek bir faktör olarak değerlendirilebilir. Mesleki yetkinlik ve donanımın hedef kitle tarafından hissedilir düzeyde nitelikli olması kişiye ve mesleğe atfedilen statüyü ve ortaya çıkacak imajı belirlemede kayda değer bir öneme sahiptir.

Öğretmenlerin toplumsal saygınlığına ve imajına olumsuz etki eden diğer önemli faktörler arasında ise özlük haklarının farklı kariyer mesleklerine göre daha düşük profilde seyretmesi gösterilmektedir. Öğretmenlerin özellikle büyük şehirlerde geçim kaygısı yaşamaları ve ekonomik gelirlerinin büyük şehrin refah seviyesinin altında kalması bu algının ortaya çıkmasında önemli bir etkendir. Mesleklere atfedilen önem ve değerin önemli belirleyicileri arasında gösterilen ekonomik göstergeler (Sunar ve Kaya, 2018) bağlamında ele alındığında Türkiye'de öğretmenliğin çok kazandıran meslekler sınıfında değerlendirilmediği görülmektedir. Türkiye'de özel okullarla birlikte bir milyondan fazla bir kitleyi oluşturan öğretmenlerin sayısal olarak büyük bir nicelikte olması devletin öğretmenlere ilişkin ekonomik iyileştirmelerini de zorlaştırmaktadır. Daha önemli bir ayrıntı ise Türkiye'de asgari ücretten bile düşük geliri olan ücretli öğretmenlerin konumudur. Ücretli öğretmenlerin iş garantilerinin ve statülerinin olmaması, başvuranlarda belirli ve üst düzeyde bir nitelik aranmaması, bir kadrolu öğretmene ödenen ücrete karşllık neredeyse üç ücretli öğretmene ücret ödenmesi mesleğin itibarını sarsan diğer ekonomi temelli nedenler arasında sayılabilir. Bayram (2009), Bozbayındır (2019) ve Ünsal'ın (2018) çalışmalarında da benzer bulgulara yer verilmiş ve öğretmen görüşlerine göre mesleğin düşük statüde değerlendirilmesinin ilk nedeni olarak maaşların düşüklüğüne işaret edilmiştir.

Öğretmenliğin saygınlığını düşüren diğer faktörler arasında ise üniversite eğitiminin yetersizliği, öğretmenlerin kendilerini geliştirmek için zaman ayırmamaları, yenilikleri takip etmemeleri, mesleğin profesyonel sayılmaması, nicel olarak çok kişinin bu işi yapması gibi etkenler sıralanmıştır. Özellikle satın alma gücünün etkisiyle ortaya çıkan çeşitli statü sembollerinin ve göstergelerinin toplum katmanlarında, 
yapılan işle, kazanç düzeyiyle ve atfedilen statüyle arasında bir ilişki olduğunu göstermesi bakımından önemlidir (Aydın, Canavar ve Akkın, 2018; Ceylan, 2011; Güven, 2010). Ekonomik İşbirliği ve Kalkınma Teşkilatı'nın (OECD) “Bir Bakışta Eğitim 2018” raporuna göre Türkiye OECD ülkeleri içerisinde öğretmen ücretleri bakımından son sıralarda yer almaktadır (Organisation for Economic Cooperation and Development [OECD], 2018). 2015 PISA'da ilk sırada yer alan Singapur'daki öğretmenlerin kazançları Türkiye'deki öğretmenlere göre dolar bazında neredeyse iki katı civarında seyretmektedir (Göçen-Kabaran ve Görgen, 2016). Bu veriler ışığında ele alındığında öğretmenlerin Türkiye' de ekonomik göstergelerinin iyileştirilmemesi halinde toplumsal statüsünün bu değişkene bağlı olarak düşük kabul edilmesi kaçınılmaz görünmektedir.

Farklı ve önemli diğer bir bulgu ise yazılı, görsel ve sosyal medyaya yansıyan öğretmen temalı haberlerin içeriklerine ilişkindir. Kitlelerin bilincini ve algısını şekillendirmede önemli bir güç kaynağını oluşturan medya araçlarında öğretmenlerin olumsuz aktörler olarak belirli aralıklarla paylaşılması ve servis edilmesi öğretmenlere göre toplumda mesleğin saygınlığını örselemektedir. Özellikle sosyal medya aracılığı ile kısa zamanda geniş kitlelere erişen haberlerin doğruluğunun teyit edilmesi söz konusu dahi olmadan paylaşımların yapılması önemli bir toplumsal algı oluşturabilmektedir. Akbaba-Altun ve Kirkit'in (2005) çalışmasında basına yansıyan öğretmen ve yönetici haberlerinde ilk sıralarda şiddet, ekonomik durumlar, hukuki konular yer almaktadır. Çetin ve Demirkasımoğlu'nun (2015) araştırmasında da benzer bulgulara değinilmiş ve basına yansıyan etik dışı öğretmen davranışlarının başında taciz, ayrımcllık, terör, ihmal ve şiddete yer verilmiştir.

Sosyal medya kullanıcısı olan öğretmenlerin kendi ağları üzerinden yaptıkları paylaşımların içerik ve niteliğinin mesleğin statüsüne ve toplumdaki temsiline yaraşır şekilde olması gerektiğini savunan öğretmenler olduğu gibi bu alanın yapılan meslekle bir bağı olmadığını ve herkesin kişisel alanı olduğunu belirten öğretmenler de katılımcılar arasında yer almaktadır. İlk argümanı savunanların temel gerekçesi, toplumun öğretmenleri her ortamda öğretmen kimliği ile kodlamasıdır. Bu gerekçeden dolayı öğretmenlerin sadece okulda değil hem gerçek dünyada hem de sanal ortamlarda bu kimliğin değerini aşındırmaktan imtina etmelerine vurgu yapılmaktadır. Bu gerekçe sürdürülen kimlik algısı ile doğrudan ilintilidir. Taşınılan bir kimliğin sadece kurum içinde değil kurum dışında da rol ve davranışları biçimlendirdiği düşüncesi bu yaklaşımı beslemektedir. Bu yaklaşıma göre toplumun algı ve değerlendirmeleri gündelik hayatın her alanında bulunmaktadır. Diğer argümanı savunanlar ise sosyal ağların kişisel bir alan olarak mesleki kimlikten bağımsız şekilde yönetilebileceğini ve mesleki rol ve davranışların mesleğin yapıldığı yer ile sınırlandırılması gerektiğini ileri sürmektedir. Öğretmenlerin insanlar nezdinde oluşturduğu imajı bireysel roller, davranışlar, iletişim becerileri, beğeniler vb. oluşturduğu için ve öğretmenler daha seçkin ve entelektüel bir vasıfta tahayyül edildiğinden, aileler kendi çocukları için örnek olarak öğretmenleri işaret ettiğinden ilk argümanı savunan öğretmenlerin güçlü toplumsal dayanakları Türkiye örneklemi üzerinden bulunduğu ileri sürülebilir.

Öğretmenlerin toplumsal statü ve saygınlıklarına zarar veren diğer bir faktör olarak ise siyasilerin, bürokratların ve yöneticilerin zaman zaman yazılı-görsel basına ve diğer medya araçlarına yansıyan olumsuz değerlendirme, söz ve davranışları belirtilmektedir. Üst yönetim kademeleri tarafından yapılan bu etik ve doğru olmayan çıkışların toplumda öğretmenlere yönelik olumsuz bir anlayışın yaygınlık kazanmasına sebep olduğunun altı çizilmekte hatta bu söylemlerden bazı kişilerin güç alarak öğretmenlere şiddet uyguladıkları da dile getirilmiştir. Nitekim Ünsal ve Bağçeci'nin (2016) araştırması da paralel bulgular içermekte ve öğretmenlere göre saygınlığın sağlanmasında ya da kaybedilmesinde en önemli aktör olarak bakanlık ve siyasi aktörler işaret edilmektedir. Yıldız ve Ünlü'nün (2013) bu yöndeki metaforik çalışmasında öğretmenler kendilerini "her gelenin ezdiği paspasa" ya da "her önüne gelenin söz söyleme hakkının olduğu bir kişiye" benzetmekte ve bu durumun kronik bir soruna dönüştügüne vurgu yapılmaktadır.

Sonuç olarak öğretmenlerin Türkiye örneklemi üzerinden ele alındığında özellikle cumhuriyetin ilk yıllarından itibaren yükselen idealist, topluma önderlik ve liderlik eden, kuşatıcı, bilge rollerinin aşınması çeşitli gelişmeler ve dönüşümler etrafında hızlanmış görünmektedir. Bu faktörlerin bir veya birden fazlasının öğretmenlerin mesleki statüsüne, saygınlığına ve toplumsal imajına zarar verdiği görülmektedir. Ek olarak, öğretmenlerin toplumsal statü ve saygınlıklarını akademik başarı veya sınav sonuçları üzerinden 
değerlendirme eğiliminin gittikçe yaygınlık kazanmaya başlaması, öğretmeni sadece öğretici tarafı ile değerlendiren ve yansıtan eksik ve indirgemeci bir taraf içermektedir.

\section{Öneriler, Sınırlılıklar ve Uyulan Etik İlkeler}

Özellikle üst yönetim kademelerinin ve siyasi aktörlerin öğretmenlerin toplumsal saygınlıklarını zedeleyecek ifade ve davranışlardan kaçınması önemli görülmektedir. Bunun yanında öğretmen yetiştiren fakülte ve bölümlere öğrenci alımında alternatif seçme ve değerlendirme usullerinin belirlenmesi, akademik ve sosyal yönü güçlü kişilerin bu mesleğe yönlendirilmesi ve üniversite eğitimi esnasında oldukça donanımlı şekilde bir eğitim hayatının sunulması mesleğin saygınlığına katkı sunacaktır. Sürekli öğrenmeyi, öğretmenin en önemli yönünün topluma yön verecek entelektüel ve lider vasfının olduğunu, mesleki gelişim ve öğrenmeleri prensip haline getirmeyi üniversite öğrenimi sırasında adaylara ve mesleğin içindeki öğretmenlere benimsetmek profesyonelliğin artmasına destek sunacaktır. Medyanın meslek etiği çerçevesinde ve toplumsal rolünün ve sorumluluğunun farkında olarak öğretmen temalı haberlerin servisinde reyting kaygısı gütmeden ve toplumsal infiale neden olacak bir üslup kullanmadan paylaşım yapması isabetli olacaktır. Son olarak, kamuda çalışan öğretmenlerin özlük haklarını cazip hale getirecek planlama ve politikaların hayata geçirilmesi öğretmenlik mesleğinin toplumdaki karşıllı̆ının yükselteceği düşünülmektedir.

Araştırmada bazı sınırlılıklar bulunmaktadır. Bunlardan ilki katılımcılarda cinsiyet çeşitliliğine çok fazla yer verilmemiş olmasıdır. Sadece bir kadın katılımcı öğretmen vardır. Farklı çalışmalarda kadın okul yöneticilerine ve öğretmenlere yer verilebilir. Diğer önemli bir sınırlılık ise katılımcı öğretmenlerin yaş aralığının ve mesleki deneyimleridir. Eski kuşak sayılabilecek nitelikte yaş aralığında bulunan ve uzun süreli mesleki deneyimi olan öğretmenlerin mesleklerine ilk başladıkları dönemler ile günümüzdeki öğretmen saygınlığını daha iyi karşılaştırabileceği düşünülmektedir. Farklı çalışmalarda bu türden öğretmenler çalışma grubu içine katılabilir. Başka bir sınırlılık ise Türkiye'deki coğrafi bölgelere göre maksimum çeşitliliğe dayalı bir örneklemin oluşturulmamasıdır. Farklı araştırmalarda bu çeşitliliğe yer verilebilir.

Araştırmacı bu süreçte mümkün olduğu kadar tarafsız şekilde konumlanmış ve araştırma problemi etrafında veri elde etmeye çalışmıştır. Ayrıca işbirliği sağlamak adına katılımcılara karşı oldukça saygılı ve onlara fiziksel ya da psikolojik bir zarar verecek söz ve davranışlardan kaçınmıştır. Araştırmacı bu süreçte elde ettiği veriyi titiz ve doğru şekilde analiz etmeye çalışmıştır. Katılımcıların cevap vermek istemedikleri soruları atlayabilecekleri, diledikleri yerde ses kaydını kesebilecekleri ve dilerlerse ses kayıtlarının kendileri ile paylaşılabileceği bilgisi de verilmiştir. Son olarak, araştırmacı raporunu yazarken yararlandığı tüm referans kaynaklara atıf yapmış ve kaynakçada bunlara açık künye ile yer vermiştir.

\section{Yazar(lar)ın Beyanı}

Araştırmacıların katkı oranı beyanı: Araştırmacı çalışmanın tümünü kendisi tasarlamış ve tüm aşamalarını kendisi gerçekleştirmiştir.

Çatışma beyanı: Araştırma sürecinde herhangi bir kişi ya da kurumla çıkar çatışması yaşanmamıştır.

Destek ve teşekkür: Bu çalışmaya desteğini sunan katılımcı okul yöneticisi ve öğretmenlere içten teşekkürlerimi sunarm.

\section{Kaynaklar}

Akbaba-Altun, S. ve Kirkit, G. (2005). Okul yöneticilerinin basındaki imajı. Kuram ve Uygulamada Ĕ̆itim Yönetimi, 41, 25-46.

Akyüz, Y. (1999). Türk eğitim tarihi. İstanbul: Alfa.

Akyüz, Y. (2012). Türkiye'de öğretmenlerin toplumsal değişimdeki etkileri. Ankara: Pegem.

Andersen, R. ve Werfhorst, H. (2010). Education and occupational status in 14 countries: The role of educational institutions and labour market coordination. The British Journal of Sociology, 61(2), 336-355. 
Öğretmenlerin Toplumsal Saygınlıklarına ve İmajlarına...

Annaberdiyev, D. (2018). Türkmen atasözlerine psikolojik bir yaklaşım. Dokuz Eylül Üniversitesi Sosyal Bilimler Enstitüsü Dergisi, 20(2), 253-273. doi: 10.16953/deusosbil.433841.

Appleyard, K. ve Appleyard, N. (2014). The professional teacher in further education. Northwich: Critical Publishing

Arslanoğlu, İ. (1992). Öğretmenin sosyal statüsü ve ekonomik durumu. Gazi Üniversitesi Eğitim Fakültesi Dergisi, 8(4), 21-33.

Aslan, B. (2015). A comparative study on the teaching profession in Turkey and South Korea: Secondary analysis of TALIS 2008 data in relation to teacher self-efficacy. Eurasian Journal of Educational Research, 15(61), 1-22.

Aydın, R., Canavar, O. ve Akkın, A. (2018). Öğretmenlerin, öğretmenlik mesleği ve öğretmenliğin toplumsal statüsüne ilişkin görüşlerinin belirlenmesi. 21. Yüzyılda Ĕ̆itim ve Toplum, 7(21), 965-990.

Baggini, J. (2005). What professionalism means for teachers today? Education Review, 18(2), 5-11.

Bayram, G. (2009) Öğretmenlerin istihdam biçimi farklılıkları ve yarattığı sorunlar: Ankara'da çalışan ücretli ve sözleşmeli öğretmenlerin görüşlerine dayal bir araştırma (Yayımlanmamış yüksek lisans tezi). Ankara Üniversitesi, Ankara.

Bek, Y. (2007). Öğretmenin toplumsal/ mesleki rolleri ve statüsü (Tezsiz yüksek lisans proje ödevi). Trakya Üniversitesi Sosyal Bilimler Enstitüsü, Edirne.

Binbaşığlu, C. (2014). Başlangıçtan günümüze Türk eğitim tarihi. Ankara: Anı Yayıncılık.

Bozbayındır, F. (2019). Öğretmenlik mesleğinin statüsünü etkileyen unsurların öğretmen görüşleri temelinde incelenmesi. Elektronik Sosyal Bilimler Dergisi, 18(76), 2076-2104. doi: 10.17755/esosder.583274.

Buyruk, H. (2013). Türkiye'de öğretmen emeğinin tarihsel dönüşümüne ilişkin ekonomi politik bir çözümleme (Yayımlanmamış doktora tezi). Ankara Üniversitesi Eğitim Bilimleri Enstitüsü, Ankara.

Büyüköztürk, Ş., Çakmak, E., Akgün, Ö., Karadeniz, Ş. ve Demirel, F. (2012). Bilimsel araştırma yöntemleri. Ankara: Pegem Akademi.

Celep, C. (2004). Meslek olarak öğretmenlik. Ankara: Anı Yayıncılık.

Ceylan, T. (2011). Toplumsal sistem analizinde toplumsal statü ve rol. Atatürk Üniversitesi Sosyal Bilimler Enstitüsü Dergisi, 15(19), 89-104.

Cruickshank, D. ve Haefele, D. (2001). Good teachers, plural. Educational Leadership, 58(5), 26-30.

Czeranowska, O. (2016). Social definition of occupational prestige. Warsaw Forum of Economic Sociology, 7(1), 67-88.

Çetin, A. ve Ünsal, S. (2018). Merkezi sınavların öğretmenler üzerinde sosyal, psikolojik etkisi ve öğretmenlerin öğretim programı uygulamalarına yansıması. Hacettepe Üniversitesi Ĕ̆itim Fakültesi Dergisi, 34(2), 304-323. doi: 10.16986/HUJE.2018040672.

Çetin, S. ve Demirkasımoğlu, N. (2015). Öğretmen ve yöneticilerin etik ve etik dışı davranışlarının basına yansımaları. Sosyal ve Beşeri Bilimler Araştırmaları Dergisi, 34, 95-110.

Çiftcioğlu, İ. (2008). Orta Asya - Anadolu ilim ve kültür köprüsü (XI-XVI. yüzy1llar). Bilig, 44, 143-172.

Demir, M. K. ve Arı, E. (2013). Öğretmen sorunları-Çanakkale ili örneği. Ondokuz Mayıs Üniversitesi Ĕ̆itim Fakültesi Dergisi, 32(1), 107-126.

Demirkasımoğlu, N. (2010). Defining teacher professionalism from different perspectives. Procedia Social and Behavioral Sciences, 9, 2047-2051. doi: 10.1016/j.sbspro.2010.12.444

Dolton, P., Marcenaro, O., De Vries, R. ve She, P. (2018). Global teacher status index-2018. London: Varkey 
Foundation.

Eskicumalı, A. (2001). Öğretmen eğitimi ve eğitim sosyolojisi dersleri. Sakarya Üniversitesi Eğitim Fakültesi Dergisi, 1, 30-37.

Erzen, Z. ve Epçaçan, C. (2018). Öğretmen görüşlerine göre öğretmenlerin toplumdaki saygınlığının incelenmesi. Journal Of Institute Of Economic Development and Social Researches, 4(9), 331-345.

Global Teacher Status Index (2018). The Varkey Foundation. Erişim adresi: https://www.varkeyfoundation.org/media/4790/gts-index-9-11-2018.pdf

Göçen-Kabaran, G. ve Görgen, İ. (2016). Güney Kore, Hong Kong, Singapur ve Türkiye'deki öğretmen yetiştirme sistemlerinin karşılaştırmalı olarak incelenmesi. Bartın Üniversitesi Eğitim Fakültesi Dergisi, 5(2), 478-495.

Güven, D. (2010). Profesyonel bir meslek olarak Türkiye'de öğretmenlik. Boğaziçi Üniversitesi Eğitim Dergisi, $27(2), 13-21$

Hargreaves, L. (2009). The status and prestige of teachers and teaching. L.J. Saha ve A.G. Dworkin (Ed.). International handbook of research on teachers and teaching (ss. 217-229) içinde. Springer International Handbooks of Education, vol 21. Springer, Boston, MA

Heinz, W. R. (2009) Redefining the status of occupations. Maclean R. ve Wilson D. (Ed.). International handbook of education for the changing world of work içinde. Dordrecht: Springer.

Hoşgörür, T. (2017). Öğretmenlerin mesleki profesyonellikleri ile saygınlıklarını yitirme kaygıları arasındaki ilişki. Kuram ve Uygulamada Eğitim Yönetimi, 23(3), 387-424.

Hoyle, E. (1980). Professionalization and deprofessionalization in education. E. Hoyle ve E. Meggary (Ed.). The professional development of teachers (s. 42-57) içinde. London: Kogan Page.

Hoyle, E. (2001). Teaching: Prestige, status and esteem. Educational Management and Administration, 29(2), 139152.

Hurst, B. ve Reding, C. (2000). Professionalism in teaching. Upper Saddle River, NJ: Prentice Hall.

Işık, S. (2014). 2000'lerde öğretmenler ve antientelektüalizm. A. Yıldız (Ed.). Öğretmenliğin dönüşümü (s. 27-57). içinde. İstanbul: Kalkedon Yayınevi.

Karasar, N. (2015). Bilimsel araştırma yöntemi. Ankara: Nobel Yayınları.

Kaya, A. (2008). Selçuklular döneminde Sivas'ta ilmi hayat ve ilim adamları. Uluslararası Sosyal Araştırmalar Dergisi , 212-242.

Keskin, D. (2012). Bitmeyen sınavlar, yaşanmayan hayatlar: Eğitimde paradigma değişimi. Ankara: Dipnot Yayınları.

Kramer, P. (2003). The ABC's of professionalism. Kappa Delta Pi Record, 40(1), 22-25.

Organisation for Economic Cooperation and Development (2018). Education at a glance: OECD Indicators. Paris: OECD Publishing

Örge-Yaşar, F. (2007). Bilgi toplumu bağlamında Türk atasözlerinde "eğitim" ve "bilgi" kavramları üzerine düşünceler. Elektronik Sosyal Bilimler Dergisi, 6(19), 146-158.

Özdemir, T. ve Orhan, M. (2019). Öğretmenlerin öğretmenlik mesleğinin imajı hakkındaki görüşleri. Trakya Eğitim Dergisi, 9(4), 824-846.

Patton, M. (2014). Nitel araştırma ve değerlendirme yöntemleri (Çev. Ed. M. Bütün ve S. B. Demir). Ankara: Pegem Akademi.

Phelps, P. H. (2006). The three RS of professionalism. Journal Kappa Delta Pi Record, 42(2), 69-71.

Smak, M. ve Walczak, D. (2017). The prestige of the teaching profession in the perception of teachers and 
Öğretmenlerin Toplumsal Saygınlıklarına ve İmajlarına...

former teachers. Edukacja: An Interdisciplinary Approach, 5, 22-40. doi: 10.24131/3724.170502.

Stronge, J. (2002). Qualities of effective teachers. Alexandria, VA: Association for Supervision and Curriculum Development.

Sunar, L. ve Kaya, Y. (2018). Türkiye'de değişen sosyo-ekonomik yapı içerisinde meslekler. L. Sunar (Ed.). Türkiye'de toplumsal tabakalaşma ve eşitsizlik (Cilt 2) (s. 1-52) içinde. Ankara: Nobel Yayınevi.

Şanlı, Ö. ve Arabacı, İ. (2017). Liselerde görev yapan öğretmenlerin örgütsel imaj algılarının bazı değişkenler açısından incelenmesi. Dicle Üniversitesi Ziya Gökalp Eğitim Fakültesi Dergisi, 31, 642-661. doi: 10.14582/DUZGEF.733.

Tehseen, S. ve Heidi, N. (2015). Factors influencing teachers' performance and retention. Mediterranean Journal of Social Sciences, 6(1), 233-244.

Tichenor, M. ve Tichenor, J. (2005). Understanding teachers' perspectives on professionalism. Professional Educator, 27(1-2), 89-95.

Topkaya, N., Altınkurt, Y., Yılmaz, K. ve Dilek, S. A. (2013). Saygınlığını yitirme kaygısı ile örgütsel sinizm arasındaki ilişkiler. Akademik Bakış, 36, 1-20.

Ulutaş, P. (2017). Öğretmenlerin bakış açısından öğretmenlik mesleğinin toplumsal statüsü (Yayımlanmamış yüksek lisans tezi). Mersin Üniversitesi, Eğitim Bilimleri Enstitüsü, Mersin.

Uygun, S. (2012). Basında öğretmen sorunları. Milli Ĕğitim Dergisi, 42(194), 72-91.

Ünal, I. L. (2005). Öğretmen imgesinde neoliberal dönüşüm. Eğitim Bilim Toplum, 3(11), 4-15.

Ünsal, S. (2018). Türkiye'de öğretmenlik mesleğinin statüsüne ilişkin bir pareto analizi. Sakarya University Journal of Education, 8(2), 111-130.

Ünsal, S. ve Bağçeci, B. (2016). Öğretmenlerin mesleki imajlarina ilişkin görüşleri ve mesleki imaja etki eden faktörler. Journal of Human Sciences, 13(3), 3905-3926. doi:10.14687/jhs.v13i3.3908.

Yıldırım, A. ve Şimşek, H. (2013). Sosyal bilimlerde nitel araştırma yöntemleri. Ankara: Seçkin Yayıncılık.

Yıldız, A. (2014). Türkiye'de öğretmenlik mesleğinin dönüşümü: İdealist öğretmenden sınava hazırlayıcı teknsiyen öğretmene. A. Yıldız (Ed.) Öğretmenliğin dönüşümü (s. 13-26) içinde. İstanbul: Kalkedon Yayınevi.

Yıldız, A. ve Ünlü, D. (2013). Metaforlarla öğretmenliğin dönüşümü: “Dün heybetli bir şelaleydik, bugün ise kurumaya yüz tutmuş dere". II. Uluslararası Eleştirel Eğitim Konferansı'nda sunulmuş bildiri. Ankara Üniversitesi, Eğitim Bilimleri Fakültesi, Ankara.

Yurdakul, S., Gür, B., Çelik, Z. ve Kurt, T. (2016). Öğretmenlik mesleği ve mesleğin statüsü. Ankara: Eğitim-BirSen Stratejik Araştırmalar. 


\section{EXTENDED ABSTRACT}

\section{Introduction}

The loss of prestige for those in the teaching profession in many countries has led to the International Labor Organization (ILO) describing teaching as a profession under siege (Yurdakul, Çelik, Gür and Kurt, 2016). The Teacher Status Index Report (2018), carried out by the Varkey Foundation, is a compendium of various indicators regarding professional esteem and prestige of teachers globally; this report found that the teaching profession in Turkey suffered a decline of more than 10 points and four places from 2013 to 2018. According to the literature, there are several reasons behind the loss of prestige for teachers. These factors include written and visual representations in social media, personal rights, ministerial management policies and insensitivity to problems, pressure from parents and guardians, teachers' failure to develop themselves, and a poorly-functioning education system (Çetin and Ünsal, 2018; Demir and Ar1, 2013; Tehseen and Hedi, 2015; Ünsal and Bağçeci, 2016). The social status and public perception of the importance of teachers have both declined significantly, and their professional identity and image have suffered greatly as a result.

Levels of status and respect afforded to different occupations vary from society to society. In Turkey, both teachers and scholars have traditionally been held in high regard; evidence for this claim exists both in preRepublic written sources and the Turkish oral tradition (Akyüz, 1999, 2012; Annaberdiyev, 2018; Binbaşığlu, 2014; Çiftcioğlu, 2008; Kaya, 2008; Örge-Yaşar, 2007). The main factors that ensured continued respect for teachers were the humanistic and professional values that the teachers represented. The gradual erosion of these humanistic and professional values has, therefore, had a direct and deleterious impact on the social standing of teachers. Various social developments and transformations, changes in the teacher training system, factors taken into account when choosing a profession, social movements, economic factors, and professional expectations were the driving forces in changing the social standing and public image of teachers (Buyruk, 2013; Işık, 2014; Yıldız, 2014).

While it is reasonable to assume that a high level of social standing and prestige would have a positive impact on teachers' in-class practices, the inverse is unfortunately just as plausible: low levels of social standing and prestige would most likely negatively affect teachers' perspectives, motivations, and practices. However, in studies conducted on Turkish teachers and their perception of the social standing of their profession, there appears to be very little research concerning the direct connection between negative factors affecting the teaching profession and the concomitant impact they have on teachers' identity and self-image. One of the main aims of this study is to address this deficiency in the literature.

Despite some negative developments, the teaching profession is still one of the most reputable and respected occupations in the world. Although there are different research findings regarding the factors that have negatively affected both the reputation and public image of the teaching profession, this study aims to reveal common factors based on the shared experiences of teachers as well as their subjective perceptions and appraisals.

\section{Method}

This study was designed in accordance with qualitative methods of descriptive research design as it contains comprehensive descriptions of teachers' experiences (Büyüköztürk, Çakmak, Akgün, Karadeniz and Demirel, 2012). This descriptive model aims to describe a situation that existed in the past and continues on to the present day (Karasar, 2015). The working group for the study was formed using the maximum variation sampling method in order to deal with the problem from a broad perspective and from various angles. Ten teachers from different branches who all had different levels of seniority and who were members of an educators' union in Turkey participated in the study. Priority was given to volunteer participants while forming the working group. In addition, working in different districts and not interviewing more than two teachers at the same school was made a priority in order to maintain maximum diversity.

\section{Results}

The data from the study indicates that the main factors that have a negative impact on teachers' social 
standing and public image can be summed up in four main headings: a decrease in professionalism, a decrease in personal rights, news coverage in the media, and the discourse and behavior(s) of politicians and bureaucrats.

\section{Conclusion}

Teachers in Turkey have, especially since the declaration of the Republic of Turkey, traditionally been seen as community leaders who represent the humanistic values and ideals of their society. Over the years, many factors have come into play which have harmed teachers' professional status, social standing, and public image. In addition, the increasing tendency of teachers to prioritize their social status and reputation over academic achievement and/or exam results is primarily a result of a deficient and reductionist approach that evaluates teachers solely as instructors of academic material. 